\title{
A Perspective on Blended-Learning Approach through Course Management System: Thailand's Case Study
}

\author{
Nalin Simasathiansophon, Member, IACSIT
}

\begin{abstract}
Blended-learning approaches are now widely used in Thai education. Most of schools and universities have attempted to use the innovative learning approach to interact with students as well as to deliver education resources to them. E-learning, for instance, has been commonly combined with traditional classroom setting. One of the most popular e-learning techniques that has been adopted in Thai education is course management system (CMS). Recently, course management system plays the important role for students who require a time schedule flexibility. This has also created more chances for student interactions with teachers as well as peers through online discussion site. Furthermore, using CMS allows students to access the contents anytime from inside and outside the classroom.This study analyses the perspective of students and teachers on CMS; discusses benefits and challenges of blended-learning approach; recommendshow to effectivelyadapt traditional classroom setting with blended-learning.The results illustrated positively perspective from both students and teachers. However, active learning environment and responsibility of students should be enhanced when adapting blended-learning approach.
\end{abstract}

Index Terms-Blended-learning approach, course management system, e-learning, education technology.

\section{INTRODUCTION}

Currently, technology application has been widely used for education in Thailand. There is a provision of student-centered approach, in which learners are fully developed according to their potentials. The main strategy of education development of the Ministry of Education $2012-2015$ is to equalize education to international level through the usage of modern education technologies [1]. Education technology, sometimes termed EdTech, is the study and ethical practice of facilitating e-learning, which is the learning and improving performance by creating, using and managing appropriate technological processes and resources. These technologies can refer to both hardware and systems. Tablet computer, for example, is hardware that Thai government introduced for primary school students in order to enhance student learning efficiency.

After the strategy of the Ministry of Education has been announced, educational institutions are attempting to adopt modern education technologies with learning activities.Blended-learning, for instance, isa very famous approach among higher educational institutions in Thailand.It involves the integration of traditional classroom face-to-face learning experiences with e-learning experiences

Manuscript received August 25, 2013; revised November 11, 2013.

Nalin Simasathiansophon is with International College, Suan Sunandha Rajabhat University, 1 U-Thong Nok Rd., Dusit, Bangkok, 10300, Thailand (e-mail: nalin.si@ssru.ac.th, and nalin.sima@gmail.com).
[2]. Indeed, blended learning approaches are increasingly implemented in several learning settings. Reference [3] suggested that the emphasis so far has been mostly related to the delivery aspects of technology which concerns access to instruction and information. In fact, relatively little attention has been paid to learning design technology in Thailand. Most universities tend to select appropriate learning technologies, and designing activities based on a single criterion - availability.

The study of [4] "The Internet and Education for the Future" stated that the total of Internet users in Thailand increased since 2000. With cost effective, the Internet access available in Thailand has been augmented. Since then, the styles of e-learning being used in Thailand are web-based instruction, web-based interactive learning environments, and web-based multimedia presentations [5]. The research of Intrapairote and Srivihok [6] illustrated that there wereincreasingly of using e-learning as the web-based pedagogy among universities in Thailand.

Among those e-learning techniques, web-based interactive learning environments, also known as a Virtual Learning Environment (VLE), or a Course Management System (CMS) has beenpopularly adopted in high education. The reason is that its platform could be use with almost all devices, such as laptop, desktop computer, smartphone, or even tablet computer. These devices have been classified as basic learning technologies in which it delivers contents, interaction forum, and learning activities.

The purpose of this paper is, firstly to analyse perspective of students and teachers in International College, Suan Sunandha Rajabhat University who used the CMS. Secondly, benefits and challenges of facilitatingblended-learning approach will be discussed. Finally, the way of effectively use blended-learning approach will be recommended.

\section{LITERATURE REVIEW}

There are hundreds of articles relating to 'blended learning approach' has been written and published. For instance, the study of Ausburn [7] examined elements of the course design in blended learning environments that combine face-to-face contact with web-based learning. A survey questionnaire had been developed to assess a number of variables, including gender, learning strategies, initial level of technology skills, pre-course experiences with technology-based learning, and number of pre-course experiences with self-directed learning. She also asked her participants to select and rank their preferred course elements and instructional goals. Ausburn found that students with different characteristics have different preferences in terms of course features and instructional goals. She also suggested that some differences 
in learning came from the different in gender, preferred learning strategies, and past experience with technology and self-directed learning.

This also supported by So and Bonk, who examined the roles of blended learning approaches in computer supported collaborative learning (CSCL) environment [8]. The research was conducted by using the Delphi technique to enable researchers to recruit experts from all over the world. SurveyShare, a web-based survey tool, had been used for the study in order to overcome limitations in Delphi process using paper-based surveys. The result indicated that blended learning approaches are useful for communication and knowledge co-construction perspectives, especially flexibility and time-efficiency are advantages of this approaches. An interesting result is that the effective collaboration will depend on how the course is designed to involve interaction with others. Thus, the authors suggested that instructors need to carefully design the degree of interactive involvement within the course.

In the Australian study, a blended learning approach has also been widely adopted in higher education. Delaney et al. [9] studied the adoption of a blended learning approach to teaching the first year accounting course at one of a large Australian universities. A pre and post survey had been conducted to assess student's views on this approach. The result of the study suggested that students consider the blended approach as a positive innovation to their learning experience. The result indicated that adopting blended learning environment has a favorable impact on student learning outcomes, their overall satisfaction with the course and student performance with respect to overall assessment.

\section{Methodology}

\section{A. Research Framework}

The research is a pilot project that used International College, Suan Sunandha Rajabhat University, Thailand as the case study. It is a survey research that aims to explore benefits and challenges of blended-learning approach through the usage of CMS from student and teacherperspectives. The subjects have been selected from students and teachers who were studying and teaching in International College, Suan Sunandha Rajabhat University at second semester, 2012 academic year. The sample is convenience sampling, consists of two groups: 112 students from third year, and 18 teachers.

\section{B. Data Collection}

The survey instrument consisted of three sections: general information; experience; and opinion. The first section contained four questions requesting gender, type of hardware that students and teachers mostly use, and the usage of CMS. The second section included students and teachers responded on a scale of (1) totally disagree to (5) totally agree. These questions focused on their experiences relating to the usage of CMS, including attitudes to time flexibility, convenience, and skill development. The third section is an open-end question asking their opinions about using blended-learning approach whether it can assist them in 1) their learning/teaching area, 2) improve the performance in assessment, and 3) to meet educational objectives.

\section{REsults}

The perspective of students and teachers who uses modern education technologies as a blended-learning approach has been analysed. The results outline the benefits and challenges of blended-learning approach for each constituent group as well as recommend how to efficiently use modern education technologies for blending with traditional teaching technique.

\section{A. General Information}

A summary of the first section is provided in Table I. The most preferring type of hardware for students is laptop due to its functionality as well as portability. Meanwile, the majority of teachers preferred to use desktop computer as hardware. The survey students said that they use laptop for searching and doing assignment during class time and outside of class time. It should be noted that there is a growing trend of using smartphone as education technology among students. This is probably because Third Generation (3G) MobileCommunications system makes smartphone more convenient and even faster to access software. On the other hands, smartphone is not popular among teachers due to its functional limitation. While desktop computer can download or upload course content, test, and activity, smartphone is only suitable for downloading, not uploading. One of survey teacher reported that some students could not uploading their assignments into CMS so they had to submit as a hard copy. Consequently, they received a score delay. Fig. 1 illustrates type of hardwares preferences.

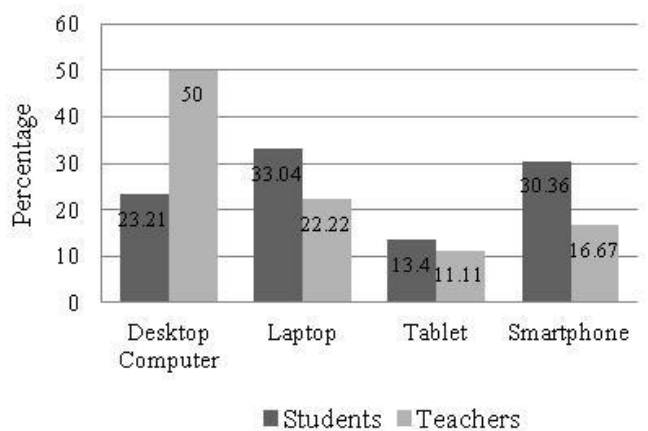

Fig. 1. Types of hardware.

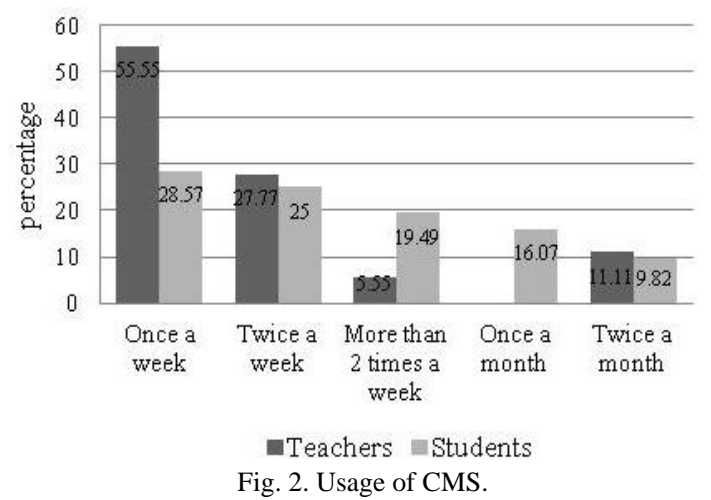

According to Fig. 2, 28.57 percents of survey students accessed CMS once a week. For this group, their primary focus was contents downloading whereas students who accessed CMS once a month tended to concentrate only on making a quiz or test. Despite this result, some students said that their testing outcome was better than taking in-class test because there was no pressure from lecturer and friends. It was more likely to be a self testing. 
TABLE I: GENERAL INFORMATION

\begin{tabular}{|c|c|c|c|}
\hline & General Information & $\begin{array}{l}\text { Student } \\
\text { sample } \\
(n=112)\end{array}$ & $\begin{array}{l}\text { Teacher } \\
\text { sample } \\
(n=18)\end{array}$ \\
\hline \multirow[t]{2}{*}{ Gender } & 1. Male & 22 & 8 \\
\hline & 2. Female & 90 & 10 \\
\hline \multirow{4}{*}{$\begin{array}{l}\text { Types of } \\
\text { hardware }\end{array}$} & 1. Desktop Computer & 26 & 9 \\
\hline & 2. Laptop & 37 & 4 \\
\hline & 3. Tablet & 15 & 2 \\
\hline & 4. Smartphone & 34 & 3 \\
\hline \multirow{5}{*}{$\begin{array}{l}\text { Usage of } \\
\text { CMS }\end{array}$} & 1. Once a week & 32 & 10 \\
\hline & 2. Twice a week & 28 & 5 \\
\hline & 3. More than 2 times a week & 23 & 1 \\
\hline & 4. Once a month & 18 & - \\
\hline & 5. Twice a month & 11 & 2 \\
\hline
\end{tabular}

For teachers, more than 50 percent spent one time a week to develop their course content on CMS. It is interesting to note that time spent on CMS depended on the design of the activities. Teachers who spent more than 2 times a week in developing their CMS usually designed activities relating to the use of communicating skills. In this case, drop box, e-mail, and discussion blogs had been used as communication tools. Those students who were assigned this kind of task became skilled in terms of communication, discussion, and even enhance their computer skills.

\section{B. Benefits}

The result from Table II shows that students who have been involved in blended-learning class are generally very positive about their experiences. They said that CMS is very helpful since they could learn course content, submit homework and share their opinion with others. Due to the improvement of standard technologies in Thailand, such as mobile phone and computer, accessing software become easily. The survey students said that it is very convenient to access course content on CMS via laptop or mobilephone. Furthermore, they enjoyedsubject with blended-learning more than traditional learning style and preferredto do blended-learning class again.

Teachers who combined blended-learning format with traditional format are also positive with their experiences. Almost 80 percents of teachers said that they would recommend using this approach to others and planned to applied a blended-learning again. The reasons for this high level of agreement are as follow.

In case of International College, Suan Sunandha Rajabhat University, all teachers are required to use CMS. It allows teachers to upload content, assignment, video clips, and web site address that related to the course contents. In advance level, some teachers conducted quiz for students and ask them to do it at home. Surprisingly, the scores of the quiz were higher than students who took a quiz in class room. This is because they faced lower pressure than the class room test.

Using blended format also reduced time spent in class. Although there was a normal lecture class, it has been decreased from three hours to only two hours, with one hourof group activities. These activities mostly took the form of group discussions and problem based learning. Students were asked to research a case study on web site in advance, and then dissolve a case in group discussion blogs using CMS whereas teacher's duty was only an assistant for them. This not only reduced time spent in the lecture, but also gave more opportunities for teachers, as a role of assistant, to communicate with students and give a feedback to their work.
The result of teacher experience is shown in Table III.

TABLE II: STUDENT EXPERIENCE USING CMS

\begin{tabular}{lc}
\hline \multicolumn{1}{c}{ Experience using CMS } & $\begin{array}{c}\text { Mean } \\
\text { Response }\end{array}$ \\
\hline \hline $\begin{array}{l}\text { I used the CMS both during the class time and outside of } \\
\text { class time }\end{array}$ & 3.12 \\
$\begin{array}{l}\text { I used the CMS effectively to learn course content, } \\
\text { complete and submit my work, and share my thoughts. }\end{array}$ & 3.47 \\
$\begin{array}{l}\text { I effectively used the tools of the CMS for } \\
\text { communicating with other students and my teacher. }\end{array}$ & 2.94 \\
$\begin{array}{l}\text { I did a variety of different things in the CMS. } \\
\text { Using the CMS helped me to learn new concepts, } \\
\text { information, and skills. }\end{array}$ & 2.65 \\
$\begin{array}{l}\text { Using the CMS helped me to schedule my time. } \\
\text { By using the CMS, I discovered the areas in which I was } \\
\text { having difficulty. }\end{array}$ & 3.59 \\
$\begin{array}{l}\text { I enjoy the subject with blended-learning more than } \\
\text { traditional learning. }\end{array}$ & 3.12 \\
I would like to do blended-learning class again. & 3.41 \\
\hline \hline & Mean \\
\hline \hline
\end{tabular}

\section{Challenges}

The study indicated that students encountered a number of challenges with blended-learning style. The three main challenges identified were; problem with responsibility for learning, difficulty with technologies, and the changing format of teaching.

The study of learner autonomy in Dhurakij Pundit University [10] suggested that Thai students had problem with capability of being responsible for their own learning. The notion of being passive learners makes it very difficult for Thai students to take their responsibility in traditional learning format. Therefore, they might be unprepared for the active learning role in blended-learning class.

Technologies related problems usually occur with the procedure for accessing the CMS. The problems range from logon information and downloading large files to accessing video clips in CMS. Moreover, students who are not familiar with CMS usually used only the download function. They rarely used discussion blog. Problems that persist throughout the semester may affect learning ability of students.

The third problem rested on the changing format of teaching. A student who was familiar with traditional learning format often has a problem with adopting themselves into blended-learning format. Some teachers discovered that their students rarely participating in CMS. Even though they downloaded course content, they rarely participated in discussion blogs or e-mail. For this group, the level of participation in learning was quite low and, if they had to, they would participate in discussion blog only they had been asked.

Another problem occurred with CMS itself. Since it is an open source for education institution, there is a limitation on 
the size of files. One survey teacher accounted that uploading video clip that contain more than $100 \mathrm{Mb}$ was very difficult. Same as uploading a file, if that file is more than $10 \mathrm{Mb}, \mathrm{CMS}$ will not accept it.

\section{CONCLUSION AND RECOMMENDATION}

The results of the study suggested that students and teachers have positive perspective with blended-learning approach. However, adopting innovative blended-learning has a favorable impact on ability to study. The results showed that students need to improve their role of active learners as well as their responsibility. The study of Vaugham [11]suggested that an institution must create the necessary policy, planning, resources, scheduling, and support systems to ensure that students will take their full responsibility of learning. A policy framework should be developed according to the nature of students. This supported by the study of Pagram and Pagram[12]. The author recommended that Thai educators should think of the following.

- E-learning should be used only as additional learning support for classroom and lecture;

- Enhance a sense of community by using tools, such as chat, discussion group;

- Always use the minimum of technology for the maximum effect (do not use all the features technically possible - let pedagogy lead design); and

- Provide learner support for both technology and learning.

The results pointed out that, initiatively, teachers should encourage student to participate in blended-learning class. Changing student habit from passive learner to active learner should be a primary objective ofThai education. Although it seems that there was a success in applying blended-learning approach with CMS, there is a room that needs to be improved especially the design of teaching and learning. In terms of technological problem, university should improve technological standard, such as increase wi-fi accessing area for student as well as enhance database system. Teachers need to make a clear understanding with students - what is a blended-learning approach, how to effectively use CMS and how to use a discussion tools in CMS in order to enhance students' ability to adopt with blended-learning format.

\section{ACKNOWLEDGMENT}

This research would not have been possible without the support of many people. N. Simasathiansophon would like to thank Asst Prof. Dr. Krongthong Khairiree who was offered invaluable assistance, support and guidance with this paper. I would like to thank my partner, Duke, for his kindness and support he has shown during the difficult time. Special thanks also to Asst Prof. Dr. Janchai Yingprayoon for giving insightful comments and constructive suggestions. I would also like to show the greatest appreciation to Ms. Bavornluck Kuosuwan for her support and encouragement. Furthermore, I would like to express gratitude to Suan Sunandha Rajabhat University to give me a supportive of both fund and suggestion in every step. Last but not least, I want to thank my parents for their endless love and support for this paper.

\section{REFERENCES}

[1] Bureau of Policy and Strategy, Strategies on Education Development of the Ministry of Education 2012-2015, Ministry of Education Meeting, Febuary, 2012.

[2] C. Williams, "Learning on-line: A review of recent literature in a rapidly expanding field,"Journal of Further and Higher Education, vol. 26, no. 3, pp. 263-272, 2002.

[3] B. Ross and K. Gage, "Global perspectives on blended learning: insight from WebCT and our customers in higher education," in Handbook of blended learning: Global perspectives, local designs, C. J. Bonk and C. R. Graham, Ed., California: Pfeiffer Publishing, 2006, pp. 155-156.

[4] S. Charmonman, "The internet and education for the future," presented at the first SEAMEO Education Congress: Challenges in the New Millennium, Bangkok, March 26-29, 2001.

[5] B. Tunhikorn, "E-learning: Learning in Learning Society," presented at the $39^{\text {th }}$ Annual Academic Forum, Kasetsart University, Thailand, February, 2001.

[6] A. Intrapairote and A. Srivihok, "An e-Learning Framework for Tertiary Education in Thailand," presented at GSB Doctoral Conference, Curtin University, Perth, Australia, November 7, 2003.

[7] L. J. Ausburn, "Course design elements most valued by adult learners in blended online education environments: An American perspective," Educational Media International, vol. 41, no. 4, pp. 327-337, 2004.

[8] H. J. So and C. J. Bonk, "Examining the Roles of Blended Learning Approaches in Computer-Supported Collaborative Learning (CSCL) Environments: A Delphi Study," Educational Technology \& Society, vol. 13, no. 3, pp. 189-200, 2010.

[9] D. Delaney, L. McManus, and C. Ng, "A blended learning approach to teaching first year accounting," in Proc. ICERI 2010Conference, 2010, pp. 4019-4020.

[10] R. Swatevacharkul, "Learner Autonomy: Teachers' Perspectives and Implications," presented at the $16^{\text {th }}$ World Congress of Applied Linguistics (AILA 2011), Beijing, China, August 23-28, 2011.

[11] N. Vaughan, "Perspectives on Blended Learning in Higher Education," in Proc. International Journal on E-Learning, vol. 6, no. 1, pp. 81-94, 2007.

[12] P. Pagram and J. Pagram, "Issues in E-Learning: A Thai case study," The Electronic Journal on Information System in Developing Countries, vol. 26, no. 6, pp. 1-8, 2006.

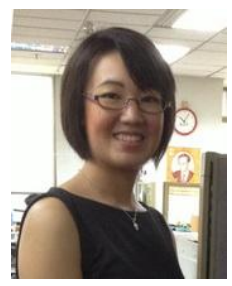

Nalin Simasathiansophon was born in Khon Kaen province, Thailand on the $23^{\text {rd }}$ March 1986. She received bachelor of art in hospitality management from Kasetsart University, Thailand in 2007. A year later, she continued her master degree in international business in University of Tasmania, Hobart, Australia and finished the degree in 2011.

After finishing her degree, she's immediately worked as a lecturer in International College, Suan Sunandha Rajabhat University for International Business program. In addition to teaching, she has conducted two researches and also be a member of International Conference of Organization Innovation. 